IJEEM: Indonesian Journal of Environmental Education and Management, Volume 1 Nomor 2 Juli 2016

\title{
PENGEMBANGAN MODEL BAHAN AJAR PENDIDIKAN LINGKUNGAN BERBASIS MASALAH UNTUK SISWA SEKOLAH DASAR
}

\author{
Bhakti Karyadi \\ Universitas Bengkulu \\ b4kt1karyadi@yahoo.com
}

\begin{abstract}
This research aims to develop teaching materials model of Environmental Education Base on Problem (EEBP) for sixth grade students elementary school. Development of teaching materials EEBP method refers to the model of instructional design. Teaching materials developed is evaluated by education practitioners, and then effectiveness test the group of six graders, with using the experimental method. Evaluation data analyzed by descriptive, while the effectiveness of the test data were statistically analyzed using t-test. Evaluation results can be concluded, the purpose and scope of the material in the teaching materials model EEBP have compatibility with the competencies to be achieved. Design of teaching materials draw a learning activities with problem solving approach. Statistical analysis showed that, the group of students who are taught using teaching materials EEBP have a better understanding than the group of students who are learning without the use of teaching materials EEBP. Conclusion of the study, teaching materials EEBP effective enough to improve the understanding of sixth grade students about concepts of ecosystems.
\end{abstract}

Keywords: Teaching Material EEBP, Environmental Education, Ecosystem Concept 


\section{Pendahuluan}

Program pendidikan lingkungan di Indoensia telah dikembangkan sejak konferensi internasional pendidikan lingkungan di Belgrade tahun 1975. Salah satu bentuk komitmen terhadap pendidikan lingkungan ditetapkannya memorandum bersama antara Departemen Pendidikan dan Kebudayaan dengan Kantor Menteri Negara Lingkungan Hidup, tentang Pembinaan dan Pengembangan Pendidikan Lingkungan Hidup.

Pada tahap implementasi program tersebut masih banyak menemukan kendala diantaranya adalah rendahnya partisipasi masyarakat untuk berperan serta dalam pendidikan lingkungan hidup, dan masih terdapat pemahaman atau persepsi dari para praktisi pendidikan, bahwa pendidikan lingkungan hidup hanya menambah beban bagi kurikulum yang berlaku (Balitbang, 2007). Hal tersebut menjadi hambatan dalam program pengembangan pendidikan lingkungan secara luas.

Berdasarkan hasil penelitian Kong (2004) pendidikan lingkungan di lima negara Asean termasuk Indonesia belum berhasil dengan baik. Berbagai faktor yang menyebabkan ketidakberhasilan tersebut antara lain disebabkan oleh (1) kurikulum yang ada terbatas pada kedalaman isi dan luasnya lingkup kajian, (2) Para guru kurang atau tidak terlatih dalam pembelajaran pendidikan lingkungan, (3) Para guru dibatasi oleh keinginan mengajar pada tuntutan materi yang akan diujikan, oleh karena itu tidak menyediakan perhatian khusus terhadap pendidikan lingkungan, (4) Pengajaran materi pendidikan lingkungan cenderung kepada aspek kognitif belum menyentuh aspek-aspek nilai dan norma lingkungan yang berkembang di masyarakat, (5) Strategi pembelajaran lebih berorientasi pada materi, (6) Pengetahuan lokal dan kondisi lingkungan yang ada kurang dijadikan sebagai sumber belajar. Kesimpulan hasil penelitian tersebut menjelaskan bahwa faktor-faktor tersebut hampir sama ditemukan pada setiap negara Asian.

Selain faktor-faktor tersebut di atas, ketersedian bahan ajar merupakan salah satu faktor yang dapat menentukan keberhasilan proses dan hasil belajar. 
Berdasarkan temuan di lapangan bahan ajar pendidikan lingkungan, khususnya untuk tingkat sekolah dasar masih sangat terbatas. Apabila dilihat dari kontens, materi yang disajikan kurang memberikan pengalaman belajar yang dapat mendorong siswa untuk belajar secara mandiri (self-instructional), serta kurang memiliki keterkaitan dengan lingkungan peserta didik. Keadaan tersebut secara tidak langsung dapat menentukan kualitas pembelajaran, khususnya pembelajaran pendidikan lingkungan pada jenjang pendidikan dasar.

Menurut Soemarwoto (2001) Pendidikan Lingkungan yang diberikan sebaiknya dapat dinternalisasikan untuk melahirkan masyarakat yang bersikap dan berperilaku ramah terhadap lingkungan. Lebih lanjut Soemarwoto (2001) menjelaskan bahwa strategi pendidikan lingkungan harus lebih menekankan pada hal-hal praktis yang sering ditemukan dalam kehidupan sehari-hari. Pendidikan lingkungan adalah suatu proses untuk mengenali nilai-nilai dan menjelaskan konsep-konsep dalam rangka mengembangkan ketrampilan, sikap yang diperlukan untuk memahami serta menghargai hubungan timbal balik antara manusia dan lingkungan biofisik maupun sosial (Unesco, 1975. UnescoUnep 1977). Dalam upaya meningkatkan kualitas pendidikan lingkungan tersebut, maka dibutuhkan perangkat pembelajaran berupa bahan ajar yang memanfaatkan lingkungan sebagai sumber belajar. Problematik lingkungan yang ditemukan dalam kehidupan sehari-hari dapat dijadikan topik bahasan dalam setiap bahan ajar melalui pendekatan pemecahan masalah (problem solving)

Pendekatan problem solving disebut juga strategi Pembelajaran Berbasis Masalah (Problem Based Learning/PBL) yaitu suatu strategi pembelajaran yang menggunakan masalah sebagai suatu pendekatan dalam memperoleh pengetahuan dan konsep-konsep penting dari materi yang diajarkan. Strategi PBL menekankan pembelajaran yang berpusat pada siswa (student-centered), kontruktivis, kontekstual, kolaboratif, dan reflektif (Arends, 2004). Secara umum strategi pembelajaran ini menyajikan suatu masalah atau fenomena yang dapat menumbuhkan minat siswa untuk belajar. Berdasarkan kesimpulan hasil 
IJEEM: Indonesian Journal of Environmental Education and Management, Volume 1 Nomor 2 Juli 2016

penelitian menjelaskan bahwa, strategi PBL cukup efektif dalam mengembangkan kemampuan berpikir kritis, kemampuan memecahkan masalah, mendorong kreativitas dan memotivasi siswa untuk belajar secara mandiri (Savery, 2006. Walker, 2009).

Dalam upaya meningkatkan kualitas pembelajaran dan memberikan pemahaman terhadap siswa tentang konsep-konsep lingkungan, maka dibutuhkan model bahan ajar pendidikan lingkungan yang disusun secara sistematis dengan kerangka desain strategi PBL. Permasalahan dan fenomena lingkungan dijadikan sebagai sumber belajar, sehingga materi yang terkandung dalam bahan ajar menjadi lebih bermakna. Diharapkan bahan ajar Pendidikan Lingkungan Berbasis Masalah (PLBM) menjadi altenatif sebagai sumber belajar yang dapat meningkatkan pemahaman siswa tentang konsep-konsep lingkungan.

Tujuan penelitian ini adalah mengembangkan bahan ajar pendidikan lingkungan berdasarkan strategi pembelajaran berbasis masalah (problem based learning/PBL) dan menguji efektivitas model bahan ajar PLBM dalam meningkatkan pemahaman siswa sekolah dasar tentang konsep-konsep ekosistem

\section{METODOLOGI}

Penelitian ini menggunakan pendekatan Penelitian Pengembangan (Research \& Development) menurut Borg and Gall (2003), sedangkan strategi penyusunan bahan ajar merujuk pada desain instruksional Dick and Carey (1996). Langkah penelitian pengembangan ditindaklanjuti dengan uji efetivitas bahan ajar PLBM melalui metode eksperimen, dengan desain randomized pretest-posttest control-group. Populasi sasaran pengguna hasil penelitian adalah siswa kelas VI SD yang tersebar dalam wilayah kerja Unit Pelayanan Teknis Dinas (UPTD) Pendidikan Kabupaten Ciamis. Pengambilan sampel penelitian dalam uji efektivitas bahan ajar dilakukan dengan teknik cluster random sampling. 
Hasil penelitian terdiri dari data kualitatif dan kuantitatif. Data kualitatif yang berkaitan dengan analsis kebutuhan materi, dan hasil evaluasi dianalsis secara deskritif interpretatif sebagai rujukan untuk mengembangkan bahan ajar PLBM. Data kuantitaif adalah skor tes dari kelompok siswa yang belajar dengan menggunakan bahan ajar PLBM (kelompok eksperimen) dan kelompok siswa yang tidak menggunakan bahan ajar PLBM (kelompok kontrol). Data tes dianalisis secara statistik dengan $t$-test, dengan bantuan program SPSS Versi 17.

\section{HASIL PENELITIAN}

Hasil penelitian ini adalah bahan ajar Pendidikan Lingkungan Berbasis Masalah (PLBM) yang dikembangkan berdasarkan desain instruksional, dan bahan ajar tersebut telah teruji-efektivitasnya. Secara rinci hasil penelitian ini dijelaskan sebagai berikut.

\section{Desain Model Bahan Ajar PLBM}

Strategi pengembangan model bahan ajar PLBM berlandaskan pada tujuan pendidikan lingkungan yang sebagaimana dituangkan dalam rumusan Konferensi Lingkungan (Unesco, 1977). Kemudian tujuan tersebut dijabarkan menjadi beberapa pokok materi bahan ajar. Fenomena lingkungan seperti kerusakan dan perubahan lingkungan, kondisi wilayah geografis, dan sosial budaya masyarakat dijadikan sebagai sumber belajar dalam pengembangan materi bahan ajar.

Langkah-langkah pengembangan bahan ajar diawali dengan identifikasi tujuan dan analisis materi, pengembangan strategi penyusunan materi, dan evaluasi terhadap produk yang dihasilkan. Berdasarkan hasil identifikasi dirumuskan beberapa tujuan yang berkaitan dengan konsep-konsep lingkungan, khusunya tentang konsep-konsep ekosistem. Pengembangan materi bahan ajar dirumuskan dalam bentuk silabus bahan ajar yang berisi standar kompetensi dan kompetensi dasar, serta indikator pencapaian hasil belajar. Desain pengembangan model bahan digambarkan sebagai berikut. 


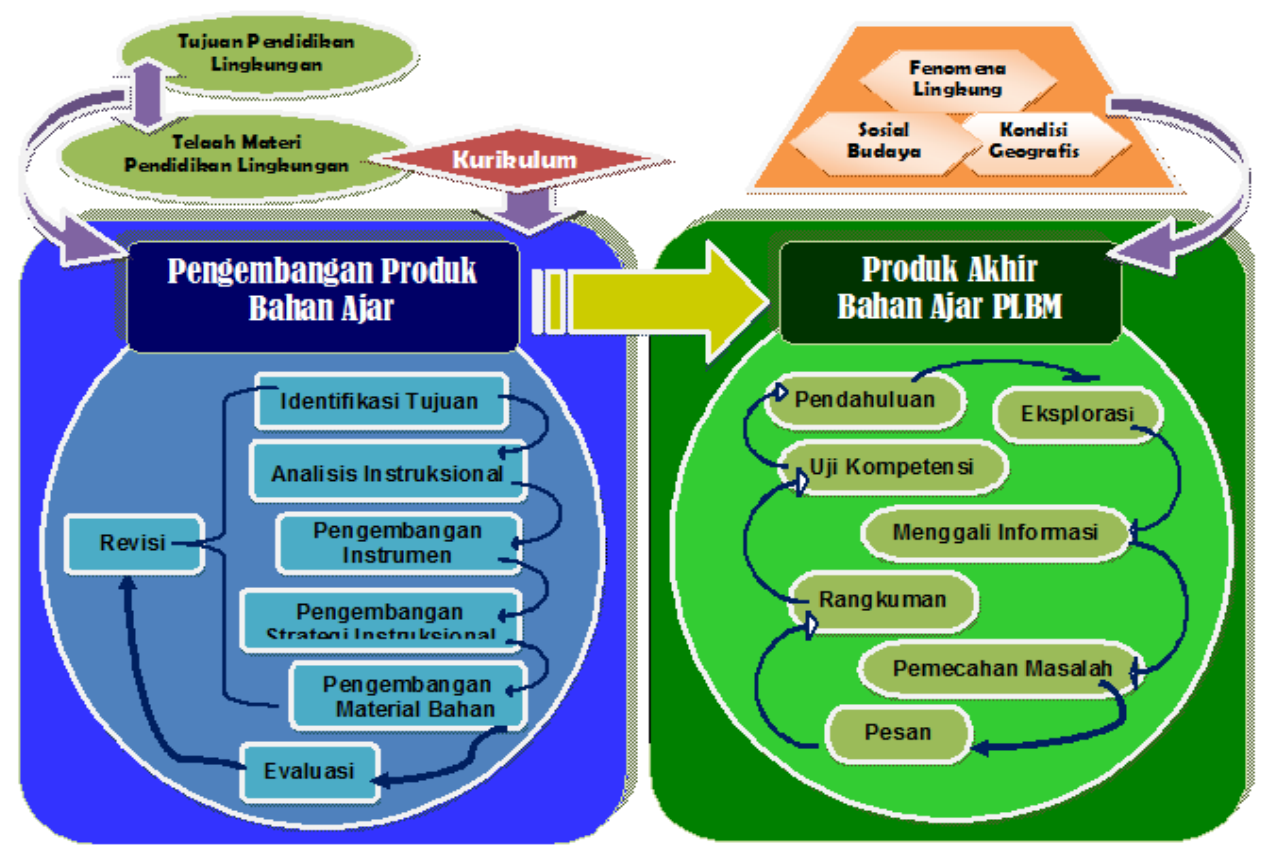

Gambar 1. Desain Model Bahan Ajar Pendidikan Lingkungan Hidup Berbasis Masalah (PLBM)

Produk akhir dari desain instruksional adalah bahan ajar Pendidikan Lingkungan Berbasis Masalah (PLBM) dengan menggunakan pendekatan pemecahan masalah (problem solving). Struktur kerangka bahan ajar yang dihasilkan terdiri dari: (1) Pendahuluan, berisi tentang judul topik bahasan dan gambar yang menunjukkan fakta-fakta kondisi lingkungan. Eksplorasi, kegiatan observasi terhadap fenomena lingungan di sekitar siswa. (3) Menggali Informasi, berisi uraian materi yang menjelaskan konsep-konsep penting. (4) Pesan Lingkungan, himbauan atau peringatan tentang pentingnya menjaga lingkungan dari kerusukan akibat tindakan manusia. (5) Masalah Lingkungan, memaparkan tentang masalah lingkungan yang terjadi di sekitar kita. (6) Rangkuman, berisi uraian singkat mengenai konsep-konsep penting. (7) Uji kompetensi, sebagai umpan balik terhadap materi yang telah dipelajarinya. Struktur bahan ajar menggambarkan sebuah aktivitas belajar ketika para siswa mempelajari bahan ajar PLBM. 
Hasil Evaluasi terhadap rancangan bahan ajar yang dikembangkan dinilai telah sesuai dengan tujuan yang ingin dicapai. Struktur kerangka bahan ajar membantu siswa untuk mempelajarnya secara sistematis, Cakupan materi pada setiap topik telah memadai untuk mencapai kompetensi yang diharapkan, yaitu memahami konsep-konsep ekosistem. Secara umum dapat disimpulkan bahwa bahan ajar PLBM telah memenuhi syarat dan layak untuk diuji lebih lanjut (uji efektivitas).

\section{Efektivitas Model}

Pengujian efektivitas bahan ajar dilakukan dengan menggunakan metode eksperimen. Uji efektivitas ini dilakukan dengan membandingkan skor postes antara kelompok eksperimendengan kelompok kontrol. Rata-rata skor postes kelompok eksperimen lebih tinggi $(94,70)$ dibanding dengan kelompok kontrol $(90,47)$. Hasil analisis statistik dengan t-tes diperoleh bahwa skor postes kedua kelompok tersebut tidak menunjukkan perbedaan yang sangat berarti dengan nilai signifikansi $0,174>p$ 0.05. Sedangkan hasil analisis rata-rata gain score dari kedua kelompok tersebut menunjukkan perbedaan yang sangat berarti dengan nilai signifikansi $0,001<\mathrm{P} 0.05$. Rata-rata gain score kelompok eksperimen mencapai 11.50 sedangkan kelompok kontrol mencapai 7,73. Hasil analsis uji efektifitas dapat dilihat pada tabel berikut.

Tabel 1. Hasil Analisis Ujibeda pada kelompok eksperimen dan kontrol

\begin{tabular}{|c|c|c|l|}
\hline Kelompok Uji & Rata-rata & $\begin{array}{c}\text { Nilai Signifikansi } \\
\text { (2-tailed) }\end{array}$ & Keterangan \\
\hline Postes : Eksperimen - & 94,70 & 0,174 & Tidak Berbeda \\
Kontrol & 90,47 & Berbeda \\
Gain Score : Eksperimen - & 11,50 & $0,001^{*}$ & \\
Kontrol & 7,73 & & \\
\hline
\end{tabular}

$*<(0,05)$ 
Hasil tersebut menggambarkan bahwa siswa yang belajar dengan bahan ajar PLBM memperlihatkan peningkatan pemahaman yang lebih tinggi dibandingkan dengan siswa yang belajar tanpa menggunakan bahan ajar PLBM. Hal ini menunjukkan bahwa bahan ajar PLBM memberikan kontribusi lebih baik terhadap hasil belajar siswa.

\section{PEMBAHASAN}

Bahan ajar yang dikembangkan berisi informasi tentang konsep-konsep dasar lingkungan yang dapat melibatkan siswa untuk belajar secara aktif dalam mengonstruksi pengetahuan melalui prinsip-prinsip dan karakteristik PBL (Graff, 2003). Pengembangan materi tidak hanya menekankan pada penguasaan konsep saja, tetapi pengubahan sikap dan pola pikir siswa agar lebih peduli terhadap masalah lingkungan, dan mampu menerapkan prinsip-prinsip kelestarian lingkungan. Dalam hal ini peserta didik diarahkan untuk memahami lingkungan dengan cara mengenalkan kondisi lingkungan, mengamati masalahmasalah dan isu-isu lingkungan, serta menyikapi secara tepat masalahmasalah lingkungan yang ada dan yang mungkin terjadi. Melalui strategi ini diharapkan akan terbentuk perilaku peserta didik yang ramah terhadap lingkungan.

Hasil analisis uji beda skor postes antara kelompok eksperimen dengan kontrol menunjukkan bahwa kedua kelompok tersebut tidak memperlihatkan perbedaan. Hal ini menggambarkan bahwa pengetahuan kelompok siswa yang belajar dengan menggunakan bahan ajar PLBM dengan kelompok siswa yang tidak menggunakan bahan ajar PLBM memiliki pemahaman ekosistem yang relatif sama. Pengetahuan dan informasi tentang konsep-konsep ekosistem yang diperoleh oleh siswa tidak hanya bersumber dari bahan ajar PLBM saja, tetapi juga dapat diperoleh dari buku atau sumber lainnya. Merujuk pada kurikulum yang sedang berjalan (KTSP), materi yang terdapat dalam bahan ajar PLBM memiliki keterkaitan erat dengan topik bahasan pada mata pelajaran lain yang diberikan pada semester yang sama. Kondisi tersebut tentunya 
IJEEM: Indonesian Journal of Environmental Education and Management, Volume 1 Nomor 2 Juli 2016

memberikan kontribusi dalam meningkatkan skor postes sebagai hasil belajar siswa pada kelompok kontrol. Gambaran peningkatan hasil belajar siswa dari kedua kelompok eksperimen dan kontrol dapat dilihat pada grafik berikut.

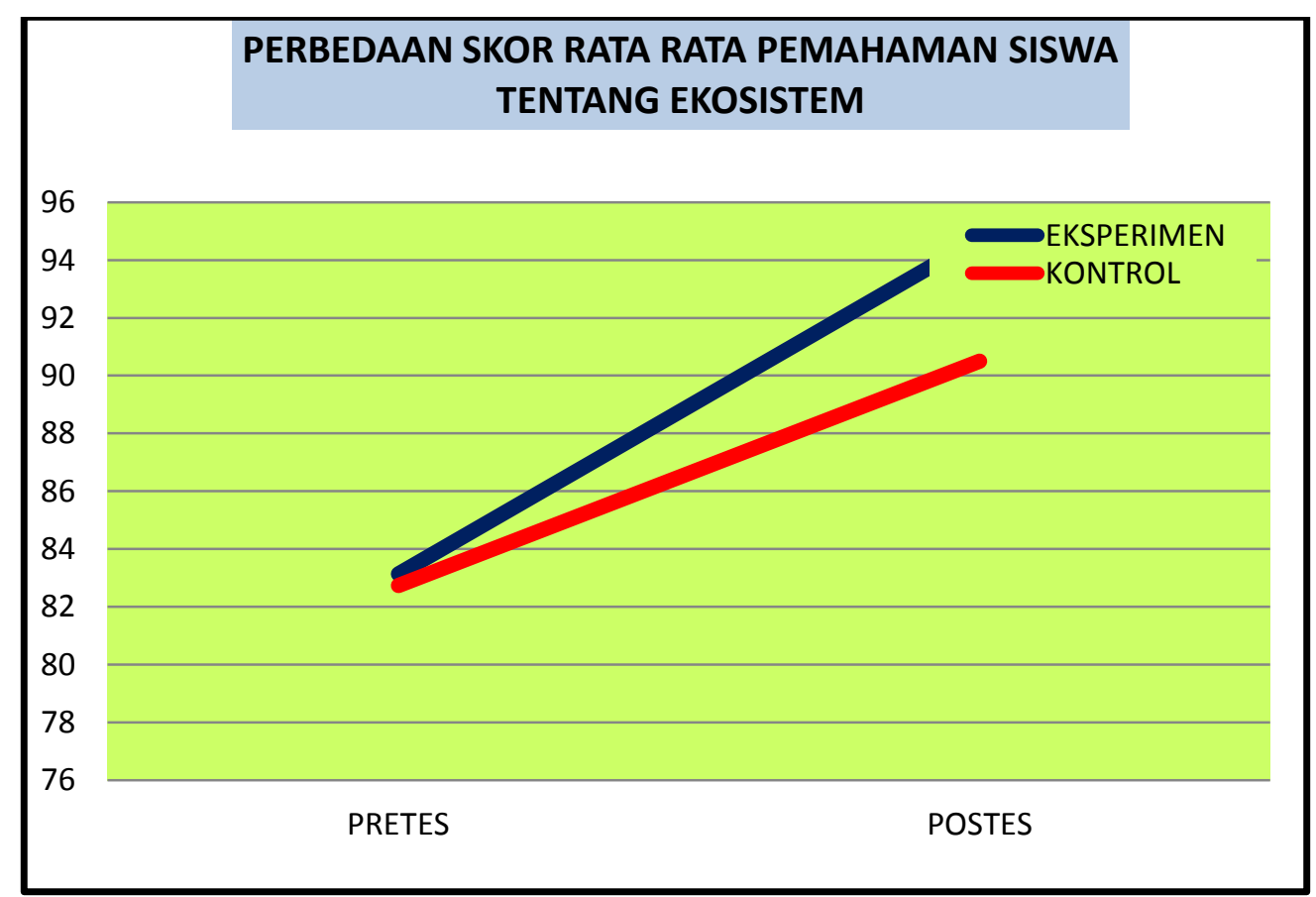

Grafik 1. Perbedaan rata-rata skor pretes dan postes kelompok eksperimen dan kontrol dari hasil uji efektivitas bahan ajar PLBM

Berdasarkan grafik di atas memperlihatkan bahwa kedua kelompok siswa tersebut memiliki skor pretes yang tidak jauh berbeda. Skor pretes kelompok eksperimen sebesar 83.13, sedangkan kelompok kontrol mencapai 82.73. Hal tersebut menggambarkan bahwa kelompok siswa yang terlibat dalam uji coba ini memiliki pengetahuan awal yang sama, khususnya tentang konsep-konsep ekosistem. Pada kelompok eksperimen terjadi peningkatan pemahaman yang lebih tinggi dibandingkan dengan kelompok kontrol. Hal ini didukung oleh ratarata gain score kelompok eksperimen $(11,50)$ lebih tinggi dibandingkan kelomppok kontrol $(7,73)$. 
Merujuk pada hasil gain score menjelaskan bahwa peningkatan pemahaman siswa yang belajar dengan menggunakan bahan ajar PLBM lebih baik dibandingkan dengan kelompok siswa yang tidak menggunakan bahan ajar PLBM. Dengan demikian bahan ajar PLBM yang digunakan sebagai sumber belajar memberikan kontribusi terhadap hasil belajar kelompok eksperimen.

Berdasarkan hasil uji efektifitas diketahui, bahwa bahan ajar PLBM mampu meningkatkan pemahaman siswa kelas VI SD tentang konsep-konsep ekosistem. Dengan meningkatnya pemahaman diharapkan dapat meningkatkan kemampuan untuk berpikir secara kritis dalam menanggapi masalah lingkungan. Menurut hasil penelitian Rhedana (2012) bahwa model pembelajaran berbasis masalah dapat mendorong siswa untuk berpikir secara kritis dan kreatif dalam memecahkan masalah yang dihadapinya. Proses PBL mendorong siswa untuk mengekplorasi informasi dan menemukan pengetahuan baru dalam upaya memecahkan masalah berdasarkan sumber daya pembelajaran yang diperolehnya (Kolmos, 2007). Hasil yang sama juga diperoleh dari penelitian Walker (2009) yang menyimpulkan bahwa model PBL dapat meningkatkan kemampuan berpikir kritis, menumbuhkan inisiatif dalam bekerja, serta dapat mengembangkan hubungan interpersonal dalam bekerja kelompok.

Bahan ajar PLBM dapat memotovasi siswa untuk belajar secara aktif dengan mengkontruksi pemahamannya dengan cara melakukan eksplorasi terhadap fenomena lingkungan dan menggali informasi dalam upaya mencari solusi untuk memecahkan masalah lingkungan yang disajikan. Menurut Mauffette (2006), memberikan pengalaman belajar pada siswa melalui pembelajaran berbasis masalah dapat menumbuhkan daya tarik siswa terhadap materi yang dipelajari. Lebih lanjut Mauffette (2006) menjelaskan bahwa aktualitas dan kontekstual masalah yang disajikan dapat mendorong minat siswa terhadap suatu mata pelajaran (subjeck matter). Kesimpulan yang sama juga dikemukan dari hasil penelitian Akınoğlu (2007) bahwa pembelajaran berbasis masalah 
dapat mengembangkan sikap postif siswa terhadap pembelajaran sains, sehingga dapat meningkatkan hasil belajar. Selain itu hasil penelitian Akınoğlu (2007) menjelaskan bahwa, siswa yang belajar melalui pemecahan masalah akan memperoleh pengetahuan-pengetahuan praktis (aplikatif) untuk diterapkan dalam kehidupan sehari-hari. Dengan demikian beberapa hasil penelitian tersebut, sangat mendukung terhadap hasil uji efektivitas bahan ajar PLBM. Berdasarkan hasil uji efektifitas menggambarkan bahwa bahan ajar yang disusun berdasarkan pada pemecahan masalah dapat memberikan waktu terhadap siswa untuk mengasimilasi dan mengakomodasi informasi berdasarkan temuannya. Melalui bahan ajar PLBM siswa melakukan kegiatan eksplorasi terhadap fenomena lingkungan, sehingga mereka dapat menemukan konsep-konsep penting berdasarkan hasil penemuannya. Hasil penelitian Balım (2009) membutikan bahwa metode penemuan (discovery) dapat meningkatkan kemampuan akademik, membentuk sikap ilmiah, dan meningkatkan retensi tingkat kognitif maupun afektif. Pengetahuan yang diperoleh melalui proses pembelajaran dengan metode discovery akan bertahan lama, dan mempunyai efek transfer yang lebih baik. Merujuk pada hasil penelitian yang didukung oleh beberapa hasil penelitian terdahulu, menggambarkan bahwa bahan ajar PLBM yang dikembangkan menanamkan dasar-dasar berpikir ilmiah pada diri siswa, sehingga siswa lebih banyak belajar sendiri, mengembangkan kreativitas dalam memecahkan masalah. Hal tersebut membantu siswa untuk memperoleh pengertian dan pemahaman siswa tentang konsep-konsep ekosistem yang dipelajarinya untuk kemudian digunakan dalam memecahkan masalah, khususnya masalah lingkungan.

\section{KESIMPULAN}

Bahan ajar PLBM dirancang dalam sebuah model bahan ajar yang dilandasi oleh tujuan pendidikan lingkungan dan memanfaatkan lingkungan biofisik, serta sosial-budaya sebagai sumber belajar. Desain bahan ajar menggambarkan suatu aktivitas belajar dengan pendekatan pemecahan masalah, yang diawali 
IJEEM: Indonesian Journal of Environmental Education and Management, Volume 1 Nomor 2 Juli 2016

dengan kegiatan eksplorasi fenomena lingkungan, menggali informasi tentang konsep-konsep ekosistem, dan mengembangkan kemampuan memecahkan masalah lingkungan.

Hasil uji efektivitas diketahui bahwa rata-rata skor postes antara kelompok kontrol dan eksperimen tidak menunjukkan perbedaan yang sangat berarti, tetapi perbedaan rata-rata gain score antara kedua kelompok menunjukkan perbedaan yang sangat berarti. Dengan demikian bahan ajar PLBM cukup efektif dalam meningkatkan pemahaman siswa VI Sekolah Dasar tentang konsep-konsep ekosistem.

\section{DAFTAR REFERENSI}

Akınoğlu Orhan, Ruhan Özkardeş Tandoğan. The Effects of Problem-Based Active Learning in Science Education on Students Academic Achievement, Attitude and Concept Learning. Eurasia Journal of Mathematics, Science \& Technology Education, 2007, 3(1), h 71-81

Arends R. I,Learning to Teach, New York: McGraw-Hill Book Company, 2004

Balım, A., G. The Effects of Discovery Learning on Students' Success and Inquiry Learning Skills. Egitim Arastirmalari-Eurasian Journal of Educationa Research, 35, 1-20. 2009

Balitang. Penelitian Perilaku Sosial Anak Sekolah Terhadap Lingkungan Hidup dan Upaya Pelestarian lingkungan Hidup. Tidak dipublikasi, Balitbang Provinsi Jawa Tengah, 2007

Borg R. Walter R, dan Meredith D. Gall. Educational Research An Introduction. New York: Longman, 1983.

Dick, Walter dan Lou Carey. The Systematic Design of Instruction. New York: Longman, 2003. 
IJEEM: Indonesian Journal of Environmental Education and Management, Volume 1 Nomor 2 Juli 2016

Gall D.Mereduth, Joice P Gall, Walter R Borg.Educational Research An Introduction. New York: Allyn and Bacon. 2003.

Graff De Erik, Anette Kolmos, Characteristics of Problem-Based Learning, International. Journal, Engng, Ed.. Vol. 19, No. 5. 2003

Kolmos Anette, et al. Problem Based Learning, TREE - Teaching and Research. Journal SIG. "Problem based and project oriented learning", 10 (08), 2007 hh. 22-23

Kong, et all. Unity and diversity: South East Asia, dalam David Yencken. John Fien, and Helen Sykes (editor). Enviroment Education And Society in The Asia-Pasific Local Tradition and Global Diacouroas. London: Routed, 2004.

Mauffette Yves. The Problem in Problem-based Learning is the Problems: But do they Motivate Students? The Problem in Problem-based Learning, Journal. 2006

Rhedana I. Wayan. Model pembelajaran Berbasis Masalah dan Pertanyaan Sovratic untuk Menigkatkan Ketrampilan Berpikir Kritis Siswa. Cakrawala Pendidikan,. Th XXXI, No.3. 2012.

Savery R. John, " Overview of Problem-based Learning: Definitions and Distinctions". Interdisciplinary Journal of Problem-based Learning, 1 (1). 2006.

Schmieder, Allen A. "The Nature and Philosophy of Evironmental Education: Goal and Objectives", Trends in Environmental Education. (UNESCO). 1977.

Soemarwoto Otto. Atur Diri Sendiri: Paradigma Baru Pengelolaan Lingkungan Hidup. Yogyakarta: Gadjahmada University Press, 2001.

Walker Andrew, Heather Leary, A Problem Based Learning Meta Analysis: Differences Across Problem Types, Implementation Types, 
IJEEM: Indonesian Journal of Environmental Education and Management,

Disciplines, and Assessment Levels, Interdisciplinary Journal of Problem-based Learning, 3(1), 2009, h 14

Unesco-Unep. Final Report.Intergovernmental Conference on Environmental Education, Organlied by Unesco in co-operation with UNEP. Tbilisi (USSR) 74 - 26 October 1977.

Unesco-Unep. The Belgrade Charter.A Global Framework for Environmental Education. Organized by Unesco in co-operation with UNEP. Belgrade Yugoslavia, 22 October 1975, h, 3 